\title{
Workplace Isolation among Ethnic Employees in Remote Work Environments
}

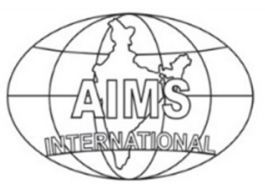

Volume 13, Number 1

January 2019, pp. 23-36

\author{
Debra Hunter \\ Charles Chekwa \\ Troy University \\ (dyhunter@troy.edu) \\ (cchekwa@ troy.edu)
}

Companies are embracing a diverse workforce and improving hiring practices to include multicultural talent. While some minorities integrate well, others fall victim to Leader-Member Exchange Theory's "out-group" category and become estranged. Out group members experience fewer opportunities for exchange relationships with leaders and key employees. In remote environments, the challenge to assimilate with supervisors and peers is complicated due to proximity related work barriers. We contend that peer relationship among minorities is a strong predictor of job satisfaction. Therefore, organizations should support increased networking opportunities for minorities in remote work environments.

Keywords: Leader-Member Exchange, Minorities, Non-Traditional Work Environments

\section{Problem Background}

Traditionally, managers and employees work alongside their counterparts. However, contemporary organizational settings utilize flexible work environments that are atypical from the traditional 9-to-5 schedules. In most instances, these employees work remotely from the organization's corporate campus and reside in various geographical locations within United States or globally. Some individuals work remotely part of the time with occasional visits to the office. Yet, others work remotely full time with unlimited access to the company intranet to facilitate assignments. Understandably, these non-traditional arrangements are also embraced by talented and highly skilled employees who will resist traditional workplace arrangements. The work flexibility and autonomy are two important features that make these arrangements attractive. On the other hand, employing individuals remotely from the company hub suggest that leaders must establish unconventional ways to communicate, engage, and support remote employees.

Recent studies on remote working reveal that remote workers are becoming more prevalent. Between 2012 and 2016, Gallop reports the number of remote employees increasing four percentage points, from 39 percent to 43 percent of the American workforce. In addition to being distal, remote workers are also spending more time working outside the four walls of the corporate campus. Thirty percent of remote workers reported spending 80 percent of their time remotely in 2016 (Athitkis, 2017).

While increased levels of job satisfaction often accompany these non-traditional work arrangements, they are not without challenges for both managers and 
employees alike. Communication and social exchanges between managers and employees in remote work environments differ from those in traditional working situations. On a corporate campus, managers are more likely to engage in frequent and face-to-face communication, share immediate feedback, provide resources and offer on-going support to employees. However, these intimate and rich exchanges may be difficult to provide to fully remote employees who have minimal or no contact with either organizational leaders or other coworkers. In such case, exchanges are typically limited to electronic emails, web meetings, and other forms of virtual communication. As a result, employees may easily disengage with the organization, managers and other coworkers.

While many remote workers thrive with minimal interaction with managers and coworkers, being estranged from the hub and key leaders can be disadvantageous. A lack of efficient communication, social support, and inclusive strategies to stay current on organizational operations has many consequences. At times, these individuals are not chosen for significant roles or assignments based on their distance from the main office. Additionally, lack of communication, support, and access to resources presents a challenge to remote employees who may become "out group" members without managerial attempts to engage employees. And as the workforce becomes more diverse, connecting remotely with individuals from various ethnic and cultures presents a greater challenge for management.

Likewise, ethnic minorities may also need greater socialization opportunities to network with organizational members. For fully remote employees, managers may be falling on certain the aspects of communication, performance development, and support that is readily available to traditional employees. This shortfall may not lead to employee job dissatisfaction, but also the risk that the employee may leave for desirable opportunities with a more inclusive organization. As a result, the organization may experience higher levels of job dissatisfaction, lowered productivity, and higher turnover.

\section{Workplace Isolation}

The concept of workplace isolation is a multidimensional construct (Bartel et al., 2012; Cooper \&Kurland, 2002; Marshall et al., 2007) that can be evaluated in terms of physical distance, communication, and information sharing. In discussing isolation, emphasis is mostly placed on the individual's interactions with colleagues, supervisors, and team members (Golden et al. 2008). The primary source of workplace isolation is caused by the physical distance from the organization's central location. When individuals are not located in the same place, they are physically separated which presents a challenge for coordination, collaboration, and socialization. Bartel (2012) acknowledges that physical isolation is the main challenge of virtual work employment. However, working virtually does not mean complete isolation as there may be interactions with others such as clients and suppliers. Yet, we are primarily focused on isolation from management and peer constituents in the workplace.

Communication (or lack thereof) and the quality of information received is another aspect of isolation in the workplace. For example, when verbal and para-verbal cues are absent, communication is more challenging and consequently vital to employee engagement (de Jong, Schalk, \& Curseu, 2008; Robbins, Judge, Millett, 8; Boyle, 2013). Curseu (2008, p. 633) suggest that "tacit knowledge transfer takes place 
through direct interactions." In other words, there are implicit cues given during face-to-face communication that have meaning to the recipient. Curseu's statement further implies that social context and knowledge are blurred when working distal, as nonverbal cues are lost during the information transfer due to lack of face-to-face contact (Jong, Schalk, \& Curseu, 2008; Wang \& Haggerty, 2009).

Yet, the extent of face-to-face interaction influences the social support received in the workplace (Marshall, Michaels, \& Mulki, 2007; Mulki \& Jaramillo, 2011; Wiesenfeld et al., 2001). For virtual employees, the lack of face-to-face contact in the workplace creates isolating conditions and adverse effects on the well-being of these individuals (Wiesenfeld et al., 2001). In addition to feelings of organizational disconnectedness, the lack of informal socialization opportunities can be problematic for virtual employees (Kurland \& Egan, 1999; Raghuram, Garud, Wiesenfeld, \& Gupta, 2001). While increased face-to-face interactions facilitates an individuals' sense of social belongingness (Sacco \& Ismail, 2014), lack of social support is associated with perceptions of isolation (Wiesenfeld et al., 2001) and feelings of loneliness (Song et al., 2014). By definition, the term virtual worker is considered to be a "remote worker," Yet, differences in opportunities for contact with others varies depending on whether the individual is partially or entirely remote. Employees who are entirely remote have few opportunities for contact with others and may experience greater feelings of isolation during an office campus visit than a partially remote employee would experience. Partially remote employees have greater opportunities for social connections and friendship opportunities through workplace friendships through direct contact with leaders, colleagues, suppliers, and customers. On the contrary, working entirely from a home-office hinders such opportunities.

Aside from occasional visits to the corporate campus, home-office workers often have no opportunities for physical contact with others. Yet, such missed opportunities may not create havoc for all employees. Sims, Szilagyi, and Keller (1976) did not find a direct association between job satisfaction and dealing with others and friendship opportunities. However, subsequent studies supported that contact with others and friendship opportunities significantly influence satisfaction at work (Levin \& Stokes, 1989; Maslach \& Jackson, 1981; Morrison, 2004).

\section{Role of Technology Employee Isolation}

Over the past few decades, the integration of technology has changed workplace dynamics. In fact, organizational job norms and communication have become more dependent upon technology than ever before. This paradigm shift is accompanied by drastic changes in the job design and work structure. Organizational designs consist of more flexible structures including virtual teams and employees who work remotely from various locations (Curseu, Schalk, \& Wessel, 2008). While this type of design has proven effective, numerous behavioral studies suggest that greater dependency on technology and less face-to-face contact may also negatively affect work-related outcomes (Gibson \& Gibbs, 2006; Martins, Gilson, \& Maynard, 2004). In virtual settings, where the dependency on technology is high and face-to-face contact is low, workers have reported decreased job satisfaction, identification with the organization, and commitment and increased physical and social isolation (Bartel, Wrzesniewski, \& Wiesenfeld, 2012; Kurland \& Egan, 1999; Mulki, Locander, Marshall, Harris, \& Hensel, 2008). Previous studies also indicate social support and the need for affiliation is also missing in virtual work settings 
(Wiesenfeld, Raghuram, \& Garud, 2001). Thus, in the absence of face-to-face contact, researchers conclude that increased virtuality leads to higher degrees of social isolation (Kenyon, Lyons, and Rafferty's, 2002). Golden, Veiga, and Dino (2008) further support these findings by suggesting a negative correlation between isolation and the degree of face-to- face interactions. The less face-to-face contact one encounters, the greater one experiences isolation from the organization and its members.

In a recent experiment, studies revealed a direct relationship between home-office applications (utilized frequently in flexible working arrangements) and an increase in individuals' work performance (Bloom, Liang, Roberts, and Ying, 2015). However, the same study reported that working from home caused worries that one's job performance was not visible and was also associated increased feelings of loneliness. While visibility is an important factor in job performance and satisfaction, it is important to acknowledge that jobs in virtual settings vary in terms of visibility ((Allen \& Griffeth, 2001). In extreme invisible situations (employee works entirely from a home office), no physical contact with others may occur. This lack of visibility, coupled with social, physical, and informational isolation, may negatively affect work outcomes (Bartel et al., 2012; Mulki \& Jaramillo, 2011).

\section{Social Exchange Theory and Workplace Isolation}

Past studies have treated the Leader-Member Exchange Theory as a construct that measures the quality of the exchange relationship between a supervisor and subordinate (Green \& Cashman, 1975; Graen et al., 1982; Graen \& Scandura, 1987). One might also understand the LMX theory form a social exchange perspective (Dienesch \& Liden, 1986; Liden \& Maslyn, 1998; Liden et al., 1997). This type of exchange would occur between individuals in the workplace and include a variety of material and non-material goods (Liden \& Maslyn, 1998). These exchanges often lead to feelings of increased gratitude, obligation, and trust (Blau, 1964).

In 1986, Dienesch and Liden suggested that LMX relationships stem from three different exchange currencies: expressions of public support (loyalty), perceived contribution to the exchange (contribution) and mutual affection (affect). Later, a fourth dimension (i.e. professional respect) was added to capture a better understanding the LMX relationship (Liden \& Maslyn, 1998). Examples of exchanges may include advice, company information, effort, social support and friendship (Krackhardt, 1990; Liden et al., 1997; Sparrowe \& Liden, 1997).

Also, it is important to note that high quality relationships can be assessed based on exchanges that can be dissimilar in nature (Liden \& Maslyn, 1998; Liden et al., 1997). For example, one LMX relationship may be based on both the leader and subordinate members' willingness to travel abroad on international assignments. Yet another LMX relationship may be grounded in the members sharing interest in a particular sport. While both of these dyads report high levels of leader-member exchange, their interactions and respective outcomes are different. Inevitably, when leaders have the opportunity to interact face to face with employees, these rich forms of exchange will be different from the types of exchanges that occur with remote employees.

Additionally, the number of social exchanges between supervisors and subordinates is also important. As the number of exchanges increase, the quality of the leader-member relationship becomes stronger. However, the number, frequency, 
and methods through which exchange can take place between supervisors and virtual employees are limited. Barriers that impact these of exchanges include the department size, time zone and geographical differences, and technical problems. For example, the number of employees under a leader's supervision could impact the frequency and method of communication and support provided. Communication may only occur in reaction to a problem or issue that needs to be resolved between the supervisor and employee. If this is the only supervisor-subordinate exchange event, such could present a problem where employees seek alternative means of obtaining performance critical information.

\section{Drawbacks of Low-Quality Exchange and Isolation}

As previously mentioned, only a fraction of individuals will have a high-quality exchange with their respective leaders. Individuals in non-traditional working arrangements are often distal from the immediate supervisor and this factor may attribute to the low-quality exchange. Accordingly, employees in the "out-group" may experience negative consequences. LMX Theory postulates that low-quality relationships are subject to less consultation and delegation, less mentoring, lower mutual influence, and a lack of trust which leads to closer monitoring. Hence, workers in the "out-group" may only comply with the formal and minimal requirements and expectations (Yukl, 2006). In some cases, these subordinates may possess fewer knowledge and skills, receive minimal support or respect, and have access to fewer resources which may lead to work-related stress. And if the employee is experiencing low-quality relationship with the leader, he will also perceive less social support in dealing with stressful issues. In fact, Glaso and Eiinarsen (2006) reported that individuals who experience frustration, violation, or uncertainty in leader relationships reported low leader-member exchange scores. Therefore, it is essential for "out-group" members to form relationships with others to reconcile the drawbacks experienced from a lower-quality exchange.

\section{Oversight of Information Sharing and Isolation}

Another concerning aspect of isolation and communication is the possible oversight of reporting and sharing of key information with remote employees. Employee perceptions of missed information and lack of access to key individuals is a major concern (Marshall et al., 2007). Missing important information required to perform tasks is commonly observed in virtual work environments (Elron \& Vigoda, 2003). Also, some virtual employees do not receive messages in a clear and timely manner (Walther, 1996). When these conditions occur, the quality of communication is negatively impacted. As the old adage states, when individuals are out of sight, they are also out of mind. This oversight delays both task-related and time-sensitive information, if not skipped entirely Gajendran \& Joshi, 2012; McCloskey \& Igbaria, 2003).

Golden et al. (2008, p. 1413) stated that "some individuals can feel professionally isolated despite working alongside coworkers." This phenomenon occurs when individuals lack access to resources and adequate connections, resulting in a failure to receive important information. When individuals fail to receive task-related information, the oversight not only impacts negative social feelings, but the likelihood of information isolation feelings also increase. Employees with the least fact-to-face interaction with others experience the highest level of information 
isolation and are more likely to be estranged from information loops (Rook, 1984; Wiesenfeld, Raghuram, \& Garud, 1999) and information exchanges (Gajendran \& Gajendran \& Joshi, 2012; Marshall et al., 2007).

Organizational justice theory supports that distribution of information among employees is as important as fair distribution of rewards (2001). This includes fair access to resources and key organizational individuals as well. When fully or partially remote employees do not have this opportunity, the purpose and meaning received from work may diminish and feelings of dissatisfaction may occur. Additionally, studies have also confirmed feelings of isolation with negative job performance (Allen \& Griffeth 2001).

\section{Workplace Isolation among Ethnic Employees}

Increased globalization and workplace integration across national and racial/ethnic boundaries is changing the composition of organizations (Nielsen 2009; Tomaskovic-Devey et al. 2006). We observe more diversity in the workforce today than during the early twentieth century (Frenkel 2003). As work becomes more interdependent among racially and culturally diverse employees, organizations and individuals alike may experience larger social consequences (DiTomaso et al. 2007). While there is contact across all groups, segregation still exists in organizations. This segregation is a major contributor to wage gaps and inequalities at large (Collins 1997; Hu $\square$ man and Cohen 2004; Kalev 2009; Maume 1999; Tomaskovic-Devey 1993). While legal, cultural, and institutional efforts continue to erode segregation in the workplace, racial and ethnic integration occurs at a slower pace, and "within workplace segregation remains high" (Tomaskovic-Devey and Stain back 2007). The reality of this phenomenon should not be ignored if organizations desire to promote environments that are inclusive of all cultures and ethnic groups.

Many organizations contend the solution to solving promoting inclusivity resides in the development of work groups and teams. Incorporating teams lays the groundwork for new relationships that may transcend across racial and ethical boundaries (Collins 1993, 1997). Work teams also offer solutions by generating prosocial opportunities and reducing silos (Smith 1996). This is especially true for minorities who are often subject to both formal and informal workplace isolation (Collins 1993, 1997). Yet, utilization of teams does not solve the problem entirely. Dissimilar employees on teams are still subject to isolation in the workplace and become further isolated when they work partially or entirely remote from the corporate campus.

In fact, interracial friendships tend to be rare (Fong and Isajiw 2000), especially in work environments where members of different racial and ethnic backgrounds are symbolically and spatially separated. Employees of different racial and ethnic backgrounds who work remotely are separated both symbolically and physically from the organization's mainstream. These are often members of the "out group" who receive fewer opportunities for exchange with organizational leaders and members than other groups. The reasons for exclusion, which results in minimal leader exchange, can be explained by understanding the formation of in group members. Homogeneous networks are formed and maintained by homophily, or individual preferences for forming relationships with others who appear similar to oneself (see Blau 1977; Marsden 1987). While this may be a natural phenomenon, there are negative consequences for individuals who are dissimilar to the leader and 
his constituents. These individuals are often excluded from communication and other benefits of leader-member exchanges. Not only do they experience reduced leadermember exchange, but they also have limited opportunities to build social networks. This problem enumerates among dissimilar employees who work remotely, as they are physically challenged by distance which limits occasions to network and develop relationships.

In situations where minorities are disconnected from the organization's mainstream, these individuals may seek belongingness and support from peers whom they share similar demographic characteristics such as ethnicity and race. Individuals in the workplace who are demographically similar most likely share similar backgrounds, experiences, and treatment; hence, these individuals are most likely to respond to situations in similar ways (Chatman, Polzer, Barsade, \& Neale, 1998). The similarity attraction theory (Byrne 1971) contents that these common experiences may enhance the degree of perceived similarity between minorities with notable demographic similarities and increase positive feelings between constituents of like characteristics. These positive feelings (positive effect) have implications for job satisfaction and productivity in the workplace.

Researchers also draw credible attention to espoused variables (less observable) such as values, beliefs, and customs that are below surface level. In fact, research indicates that deep-level perceptual similarities have a more consistent and lasting effect when compared to surface level similarities (e.g., Bauer \& Green, 1996; Harrison, Price, \& Bell, 1998; Phillips, North craft, \& Neale, 2006; Turban, Dougherty, \& Lee, 2002). These findings are consistent with LMX research suggesting that deep-level perceived similarities may be a stronger construct for predicting LMX relationships than surface level similarities (e.g., Liden et al., 1993), and have implications for peer to peer relationships as well. In other words, coworkers who share both surface-level and deep perceptual similarities are most likely to develop positive relationships. Minorities who share surface and perceptual similarities are more likely to form work friendship among each other than with supervisors or peers of dissimilar characteristics. Again, absent of established the "in-group" affiliation, these individuals will seek belonging and form relationships with peers of similar backgrounds and experiences. As such, the relationships established with peers will be foster trust, greater support, and more frequent communication than with other groups.

Given the relative social isolation experiences of racial and ethnic minorities, offering formal networking opportunities targeted to these groups would prove beneficial. These networking opportunities, either formal or informal, could possibly serve as the tie that binds dissimilar employees to the entire organization. Binding these individuals by networking would not only improve productivity, but also reduce turnover that occurs among ethnic and racial groups in organizations.

\section{Conclusion and Recommendations}

As organizations continue to find ways to cut cost and streamline operations, reducing or eliminating need for facilities, management levels, and worksites will become common(Cleaver 2000). For many companies, going virtual can eliminate

large capital expenditures for facilities, create economies of scale, and allow companies to employ workers in low-wage-rate locations (Alexander, 1997; Cleaver, 2000). Due to distance and proximity, most workers will continue to view their counterparts over videoconference screens and communicate primarily through email than ever before (Markus et al., 2000). 
This lack of worker proximity will also change the interactions and relationships between parties involved (Alexander, 1997). The change in interactions and relationships must be addressed by human resource departments if organizations desire to benefit from exchanges in the supervisor/peer or peer to peer networks. Thus, companies that go virtual should not only consider the cost-effectiveness and productivity aspects, but should maintain some aspects of organizational social interaction and create networking opportunities for minorities and others as well. Alexander (1997) contends "These boundaries (social interaction between workers) will have to be managed differently as long as technology provides anything short of a total replication of physical presence" (p. 123). Managers should not forget the fundamental aspects of human resource development based on establishing manageremployee relationships and fostering peer to peer support. Rather, they must learn to establish more conversations with remote employees across all ethnic boundaries and foster greater opportunities for networking among ethnic groups.

To facilitate greater conversations, leaders can encourage social interaction between employees by setting aside time during teleconferences for informal conversation and extending invitations to visit the corporate campus site for special activities and events. Cohen (1997) advised frequent employee discussion groups, providing routine updates, and circulating stories to reinforce company work ethics. Electronic social groups created through email listings have been shown to "exhibit many of the characteristics of face-to-face groups, such as decision making and norm formation, while consisting of hundreds of members at dozens of locations" (Finn, 1997). Also, Finholt (1997) argued for the use of digital archives or electronic bulletin boards where employees can read the opinions of other workers on various work-related topics. And present day social media sites, such as Yammer, Facebook and Twitter, provide avenues for employees to both meet electronically and share opinions with each other on work-related topics. In fact, companies can create special diversity groups to allow collaboration among ethnic employees for networking purposes.

While organizations must foster proactive employee behavior in terms of socialization and policies that encourage individual initiatives, proactive behavior should be required on the part of employees in terms of career management and problem-solving (Crant, 2000). In addition to opportunities created by employers, non-traditional employees must be proactive about learning, interacting, and communicating. Examples of proactive behavior include engaging in active communication with supervisors and peers, seeking performance-related feedback, and actively managing their career by exploring opportunities for peer to peer collaboration, growth and development. The most successful virtual employee will explore new information sources and seek collaborative experiences" (p. 30). Adopting a proactive strategy becomes increasingly important in complementing initiatives provided by organizations to create networking opportunities.

\section{References}

1. Albrecth, T. L., \& Adelan, M.B. (1987). Communicating social support. Newbury Park, CA: Sage.

2. Alexander, M. (1997). Getting to grips with the virtual organization. Long Range Planning, 30(1), 122-124. 
3. Allen, D. G., \& Griffeth, R. W. (2001). Test of a mediated performance-turnover relationship highlighting the moderating roles of visibility and reward contingency. Journal of Applied Psychology, 86, 1014-1021.

4. Anderson, C. M., \& Martin, M. M. (1995). Why employees speak to coworkers and bosses: Motives, gender, and organizational satisfaction. The Journal of Business Communication, 32, 249-265.

5. Anonymous. (1997). A virtual prototype. Training and Development, 51(5), 33.

6. Arling, P. A., \& Subramani, M. (2011). The effect of virtuality on individual network centrality and performance in on-going, distributed teams. International Journal of Internet and Enterprise Management, 7,325-348.

7. Appelbaum, Eileen and Rosemary L. Batt. 1994. The New American Workplace: Transforming Work Systems in the United States. Ithaca, NY: ILR Press.

8. Athitakis, Mark, Bar Leader, 00991031, Jul/Aug2017, Vol. 41, Issue 6.

9. Bartel, C. A., Wrzesniewski, A., \& Wiesenfeld, B. M. (2012). Knowing where you stand: Physical isolation, perceived respect, and organizational identification among virtual employees. Organization Science, 23, 743-757.

10. Blau, P. M. (1964). Exchange and power in social life. New York: Wiley.

11. Blau, Peter M. 1977. Inequality and Heterogeneity: A Primitive Theory of Social Structure. New York: The Free Press.

12. Bloom, N., Liang, J., Roberts, J., \& Ying, Z. J. (2015). Does working from home work? Evidence from a Chinese experiment. The Quarterly Journal of Economics, 130, 165-218.

13. Brehm, S. S. (1985). Intimate relationships. New York: McGraw Hill.

14. Byrne, D. (1971). The attraction paradigm. New York: Academic Press.

15. Collins, Sharon. 1993. "Blacks on the Bubble: The Vulnerability of Black Executives in White Corporations." The Sociological Quarterly 34: 3: 429-447. Collins, Sharon. 1997. Black Corporate Executives: The Making and Breaking of a Black Middle Class. Philadelphia, PA: Temple University Press.

16. Collins, Sharon. 1997. Black Corporate Executives: The Making and Breaking of a Black Middle Class. Philadelphia, PA: Temple University Press.

17. Chatman, J., Polzer, J., Barsade, S., \& Neale, M. (1998). Being different yet feeling similar: The influence of demographic composition and organizational culture on work processes and outcomes. Administrative Science Quarterly, 43, 749-780.

18. Cialdini, R.B. (1984). Influence: The new psychology of modern persuasion (pp. 163-202).

19. Cleaver, J. (2000). Out of sight. Crain's New York Business, 16(44), 31; 46.

20. Cohen, S. (1997). On becoming virtual. Training and Development, 51(5), 3032.

21. Curseu, P. L, Schalk, R., \& Wessel, I. (2008). How do virtual teams process information? A literature review and implications for management .Journal of Managerial Psychology, 23, 628-652.

22. Crant, J. M. (2000). Proactive behavior in organizations. Journal of Management, 26(3), 435462.

23. Damaske, Sarah. 2009. "Brown Suits Need Not Apply: The Intersection of Race, Gender and Class in Institutional Network Building." Sociological Forum 24: 2: 402-424. 
24. Dienesch, R. M., \& Liden, R. C. (1986). Leader-member exchange model of leadership: A critique and further development. Academy of Management Review, 11, 618-634.

25. DiTomaso, Nancy, Corinne Post, and Rochelle Parks-Yancy. 2007. "Workforce Diversity and Inequality: Power, Status, and Numbers." Annual Review of Sociology 33: 1: 473-501.

26. Dixon, K. R., \& Panteli, N. (2010). From virtual teams to virtuality in teams. Human Relations. 63,1177-1197.

27. Fine, G. A. (1986). Friendships in the workplace. IN V. J. Derlega \& B. A. Winstead (Eds.), Friendship and social interaction (pp. .185-206). New York: St. Martin's Press.

28. Finholt, T. A. (1997). The electronic office. Trends in Organizational Behavior (Journal of Organizational Behavior), 4, 29-41.

29. Fitzpatrick, W. M., \& Burke, D. R. (2000). Form, functions, and financial performance realities for the virtual organization. Advanced Management Journal, 65(3), 13-20.

30. Fong, Eric and Wsevolod W. Isajiw. 2000. "Determinants of Friendship Choices in Multiethnic Society.” Sociological Forum 15: 2: 249-271.

31. Frenkel, Stephen J. 2003. "The Embedded Character of Workplace Relations." Work and Occupations 30: 2: 135-153.

32. Fullerton, Andrew and Kathryn Freeman Anderson. 2013. "The Role of Job Insecurity in Explanations of Racial Health Inequalities." Sociological Forum 28: $2: 308-325$

33. Gardenswartz, Lee and Anita Rowe. 1995. Diverse Teams at Work: Capitalizing on the Power of Diversity. Chicago, IL: Irvin Professional Publishing.

34. Glas $\varnothing$, L., \& Einarsen, S. (2006) 'Experienced affects in leader-subordinate relationships', Scandinavian Journal of Management, 22(1): 49-73.

35. Gibson, C. B,, \& Gibbs, J. L. (2006). Unpacking the concept of virtuality: The effects of geographic dispersion, electronic dependence, dynamic structure, and national diversity on team innovation. Administrative Science Quarterly, 51,451-495.

36. Gilson, L. L, Maynard, M. T., Young, N, C, J,, Vartiainen, M, \& Hakonen, M. (2014). Virtual Teams Research 10 Years, 10 Themes, and 10 Opportunities. Journal of Management, 41,1313-1337. Giri, V. N,, \& Kumar, B. P. (2010).

37. Golden, T. D., Veiga, J. F, \& Dino, R. N. (2008). The impact of professional isolation on teleworker job performance and turnover intentions: does time spent teleworking, interacting fact-to-face, or having access to communicationenhancing technology matter? Journal of Applied Psychology, 93, 1412-1421.

38. Graen, G., \& Cashman, J. F. (1975). A role making model in formal organizations: A developmental approach. In J. G. Hunt \& L. L. Larson (Eds.), Leadership frontiers (pp.143-165). Kent, OH: Kent State Press. Graen, G. B., Novak, M. A., \& Sommerkamp, P. (1982). The effects of leader-member exchange and job design on productivity and satisfaction: Testing a dual attachment model. Organizational Behavior and Human Performance, 30, 109_ 131. 
39. Graen, G.B., \&Scandura, T.A. (1987).

Towardapsychologyofdyadicorganizing.InL.L.Cummings \& B. M. Staw (Eds.), Research in organizational behavior, (Vol. 9, pp. 175-208). The Netherlands:

JAI Press.

40. Harrison, D. A., Price, K. H., \& Bell, M. P. (1998). Beyond relational demography: Time and the effects of surface- and deep-level diversity on work group cohesion. Academy of Management Journal, 41, 96-107.

41. Hays, R. B. (1989). Friendships. In S. W. Duck (Ed.) Handbook of personal relationships: Theory, research, and interventions (pp. 391-408). New York: John Wiley.

42. Homans, George C. 1961. Social Behavior: Its Elementary Forms. New York: Harcourt Brace Jovanovich.

43. Hickman, Gill Robinson and Ann Creighton-Zollar. 1998. "Diverse SelfDirected Work Teams: Developing Strategic Initiatives for 21st Century Organizations." Public Personnel Management 27: 2: 187-200.

44. Hosseini, M. R,, Zuo, J., Chileshe, N., \& Baroudi, B. (2015). Evaluating virtuality in teams: A conceptual model. Technology Analysis \& Strategic Management. 27, 385-404.

45. Huffman, Matt L. and Philip N. Cohen. 2004. "Racial Wage Inequality: Job Segregation and Devaluation across U.S. Labor Markets." American Journal of Sociology 109: 4: 902-936.

46. Jackson, S. E., Stone, V. K., \& Alvarez, E. B. (1993). Socialization amidst diversity: Impact of demographics on work team old-timers and newcomers. In L.L. Cummings \& B.M. Staw (Eds.), Research in Organizational Behavior (Vol. 15: 45-109). Greenwich, CT: JAI Press.

47. Jehn, K. A., \& Shah, P. P. (1996). Interpersonal relationships and task performance: An examination of mediating processes in friendship and acquaintance groups. In L. N. Dosier \& J. B. Keys (Eds.), Academy of Management Best Paper Proceedings (pp. 279-283). Pleasantville, NY: Academy of Management.

48. Kalev, Alexandra. 2009. "Cracking the Glass Cages? Restructuring and Ascriptive Inequality at Work." American Journal of Sociology 114: 6: 15911643.

49. Kenyon, S, Lyons, G,, \& Rafferty, J. (2002). Transport and social exclusion: investigating the possibility of promoting inclusion through virtual mobility. Journal of Transport Geography, 10,207-219.

50. Kurland, N. B,, \& Egan, T. D. (1999). Telecommuting: Justice and control in the virtual organization. Organization Science, 10,500-513.

51. Krackhardt, D. (1990). Assessing the political landscape: Structure, cognition, and power in organizations. Administrative Science Quarterly, 35, 342-369.

52. Hellerstein, Judith K. and David Neumark. 2008. "Workplace Segregation in the United States: Race, Ethnicity, and Skill." The Review of Economics and Statistics 90: 3: 459-477.

53. Lally, R., \& Kostner, J. (1997). Learn to be a distance manager. Getting Results for the Hands-on Manager, 42(7), 6-7. (Published by the American Managment Association). 
54. Liden, R. C., Sparrowe, R. T., \& Wayne, S. J. (1997). Leader-member exchange theory: The past and potential for the future. In G. R. Ferris (Ed.), Research in personal and human resources management (Vol. 15, pp.47-119). Greenwich, CT: JAI Press.

55. Liden, R. C., \& Maslyn, J. M. (1998). Multidimensionality of leader-member exchange: An empirical assessment through scale development. Journal of Management, 24, 43-72.

56. Liden, R. C., Wayne, S. J., \& Stilwell, D. (1993). A longitudinal study on the early development of leader member exchanges. Journal of Applied Psychology, 78, 662-674.

57. Lu, M., Watson-Manheim, M. B,, Chudoba, K. M, 8: Wynn, E. (2006). Virtuality and team performance: Understanding the impact of variety of practices. Journal of Global Information Technology Management, 9, 4-23.

58. Maume, David J. 1999. "Glass Ceilings and Glass Escalators: Occupational Segregation and Race and Sex Differences in Managerial Promotions." Work and Occupations 26: 4: 483-509.

59. Marsden, Peter V. 1987. "Core Discussion Networks of Americans." American Sociological Review 52: 1: 122-131.

60. Markus, M. L., Manville, B., \& Agres, C. E. (2000). What makes a virtual organization work? Sloan Management Review, 42(1), 13-26.

61. McPherson, M. J., J. Miller, and L. Smith-Lovin. 1982. "Women and Weak Ties: Differ ences by Sex in the Size of Voluntary Organizations." American Journal of Sociology 87: 833-904. McPherson, M. J., J. Miller, and L. SmithLovin. 1986. "Sex Segregation in Voluntary Associations." American Journal of Sociology 51: 61-79.

62. Meyers, S., Knox, R., Pawloski, D., \& Ropog, B. (1999). Perceived communication openness and functional communication skills among organizational peers. Communication Reports, 12, 71-81.

63. Mouw, Ted. 2002. "Are Black Workers Missing the Connection? The Effect of Spatial Distance and Employee Referrals on Interfirm Racial Segregation." Demography 39: 3: 507-528.

64. Mulki, J. P,, Locander, W. B,, Marshall, G. W,, Harris, E. G, \& Hensel, j. (2008). Workplace isolation, salesperson commitment, and job performance. Journal of Personal Selling \& Sales Management, 28,67-78.

65. Mulki, J. P, \& Jaramillo, F. (2011). Workplace isolation: salespeople and supervisors in USA. The International Journal of Human Resource Management, 22,902-923.

66. Nielsen, Sabina. 2009. "Why Do Top Management Teams Look the Way They Do? A Multilevel Exploration of the Antecedents of TMT Heterogeneity." Strategic Organization 7: 3: 277-305.

67. Nelson, R. E. 1988. "Social Network Analysis as Intervention Tool." Group and Organization Studies 13(1): 39-58.

68. Odden, C.M., \& Sias, P.M. (1997) Peer communicaiton relationships and psychological climate. Communication Quarterly, 43, 110-115.

69. Orhan, M. A. (2014). Extending the individual level of virtuality: Implications of task virtuality in virtual and traditional settings. Administrative Sciences., 4,400-412. 
70. Osterman, Paul. 1994. "How Common Is Workplace Transformation and Who Adopts It?" Industrial and Labor Relations Review 47: 2: 173-188.

71. Oswald, D. L, Clark, E. M., \& Kelly, C. M. (2004). Friendship maintenance: An analysis of individual and dyad behaviors. Journal of Social and Clinical Psychology, 23, 413-441.

72. Quillian, Lincoln and Mary E. Campbell. 2003. "Beyond Black and White: The Present and Future of Multiracial Friendship Segregation." American Sociological Review 68: 4: 540-566.

73. Phillips, K. W., Northcraft, G. B., \& Neale, M. A. (2006). Surface-level diversity and decision-making in groups: When does deep-level similarity help? Group Processes \& Intergroup Relations, 9, 467-482.

74. Rhodes, C., \& Butler, J. S. (2010). Organizational Membership and Business Success: The Importance of Networking and Moving Beyond Homophily. Challenge (1077193X), 16(1), 33-48.

75. Ross, J. A. (1997). Does friendship improve job performance? Harvard Business Review, 75, 8-9.1.

76. Schweitzer, L, \& Duxbury, L (2010). Conceptualizing and measuring the virtuality of teams. Information Systems Journal, 20, 267-295.

77. Sørensen, Jesper B. 2004. "The Organizational Demography of Racial Employment Segregation.” American Journal of Sociology 110: 3: 626-671.

78. Sias, P. M., \& Cahill, D. J. (1998). From coworkers to friends: The development of peer friendships in the workplace. Western Journal of Communication, 62, 3, 273-299.

79. Sparrowe, R. T., \& Liden, R. C. (1997). Process and structure in leader-member exchange. Academy of Management Review, 22, 522-552.

80. Suh, A., Shin, K., Ahuja, M., \& Kim, M. S. (2011). The influence of virtuality on social networks within and across work groups: A multilevel approach. Journal of Management Information Systems, 28, 351-386.

81. Szarka, J. 1990. Networking and Small Firms. International Small Business Journal 8:10-22.

82. Tomaskovic-Devey, Donald. 1993. "The Gender and Race Composition of Jobs and the Male/ Female, White/Black Pay Gaps." Social Forces 72: 1: 45-76.

83. Tomaskovic-Devey, Donald and Kevin Stainback. 2007. "Discrimination and Desegregation: Equal Opportunity Progress in U.S. Private Sector Workplaces Since the Civil Rights Act." Annals of the American Academy of Political and Social Science 609: 1: 49-84.

84. Turban, T. D., Dougherty, T., \& Lee, F. K. (2002). Gender, race, and perceived similarity effects in development relationships: The moderating role of relationship duration. Journal of Vocational Behavior, 61, 240-262.

85. Wiesenfeld, B. M., Raghuram, S., \& Garud, R. (2001). Organizational identification among virtual workers: The role of need for affiliation and perceived work-based social support. Journal of Management, 27,213-229.

86. Wilson, William Julius. 1987. The Truly Disadvantaged: The Inner City, the Underclass, and Public Policy. Chicago: University of Chicago Press.

87. Woodard, M. D. 1988. "The Effects of Social Class on Voluntary Association Member ship among Urban Afro-Americans." Sociological Focus 21(1): 67-80.

88. Yukl, G. (2006) Leadership in Organizations (6th ed.). Upper Saddle River: Pearson Prentice Hall. 


\section{About Our Authors}

Debra Hunter is an Associate Professor of Business Administration at Troy University since 2002. She earned a Bachelors in Business Administration from the University of Georgia (with a concentration in Marketing), an MBA from Troy University, and a DBA from The University of Sarasota. Prior to teaching in academic, Dr. Hunter spend several years in Corporate America as a consultant and has experience in the insurance industry as a licensed agent. Her research interest include diversity, organizational behavior related issues and innovative teaching pedagogies.

Charles Chekwa is a full Professor of Business at Troy University. He holds a Bachelor of Science Degree in Accounting from Mississippi State University. His advanced degrees include MBA and Doctorate in Business respectively. He has published extensively in National and International Journals. Dr. Chekwa has also served as Dean of several colleges of Business in the United States. He is the Current Editor -in-Chief of International Journal of Business Research and International Journal of Applied Accounting and Finance. 